\title{
Ten Years of Atazanavir Experience: A History Page of Antiretroviral Treatment
}

\author{
MANUELA ARBUNE ${ }^{1}$, IRINA-MAGDALENA DUMITRU ${ }^{2 *}$, ADRIAN BEZNEA ${ }^{*}$, IULIAN DAN CUCIUREANU ${ }^{3}$, \\ ANCA-ADRIANA ARBUNE ${ }^{4}$, SILVIA FOTEA ${ }^{1}$ \\ 1"Dunărea de Jos" University from Galati, Faculty of Medicine, 47 Domneasca Str., 800008, Galati, Romania \\ 2"Ovidius" University from Constanta, Faculty of Medicine, 124 Mamaia Blvd., 900527, Constanta, Romania \\ 3"Grigore T. Popa" University of Medicine and Pharmacy,Faculty of Medicine, III-rd Medical Department, 16 Universitatii \\ Str., 700115, Iasi, Romania \\ 4"Carol Davila" University of Medicine, Doctoral School, 8 Eroii Sanitari Str., 050474, Bucharest, Romania
}

Antiretroviral therapy has increased the life expectancy and quality of life of patients infected with human immunodeficiency virus (HIV). Antiretroviral therapies based on Atazanavir were preferred for $a$ while, but the recommendations have been changed, once new more effective antiretroviral drugs become available. This study evaluates the experience of using Atazanavir for 10 years in $60 \mathrm{HIV}$ patients, of which $26.6 \%$ received the first antiretroviral line and $73.3 \%$ had previously received other therapies. The mean duration of exposure to Atazanavir was 4.5 years with variations between 0 and 10 years, with $43.3 \%$ of patients still continuing therapy in 2019. Hyperbilirubinemia was identified in $81.6 \%$ of patients experiencing ATV. A large proportion of patients discontinued therapy because of their jaundice or lack of adherence, although no significant adverse effects were seen. The effectiveness of ATV has been proven by the sustained immune enhancement and viral suppression, confirming the benefits of maintaining this drug as a therapy option.

Keywords: Atazanavir, unconjugated hyperbilirubinemia, HIV, $H B V$

Antiretroviral therapy (ARV) has spectacular progressed over the last 20 years, decreasing the morbidity, mortality and transmission of human immunodeficiency virus (HIV) [1]. The goals of ARV targets are to achieve and sustain full viral suppression, immune restoration, increasing survival and patients quality of life. Even if durable viral suppression is achieved, ARV does not yet cure HIV and must be taken the whole life.

To decide an antiretroviral regimen it is considering potency, safety, tolerability and convenience, in order to allow the treatment adherence. Current ARVT regimens are based on combinations of at least 3 different drugs, which may be nucleosides reverse transcriptase inhibitors (NRTIs), non-nucleoside reverse transcriptase inhibitors (NNRTIs), protease inhibitors (IP) with boosted ritonavir (r), integrase inhibitors (II) or entry inhibitors (IF, ICCR5)[2]. Nowadays, there are available 40 antiretroviral individual drugs and combinations of drugs that can be sequentially, according the personalcharacteristics of the patient [3]. Although good potency and tolerability, are proved in most current ARV regimens, long-term toxicity, drug interactions and adherence are continuing challenge [4].Used in combination with other HIV drugs, Atazanavir (ATV) is a protease inhibitor, that blocks the protease, a key enzyme for HIV replication. Unlike other IPs, ATV alters less lipid profile and has better convenience, being administered once a day.

Atazanaviris an azapeptide [5]. International Union of Pure and Applied Chemistry (IUPAC) named the formula methyl N-[(1S)-1-\{[(2S,3S)-3-hydroxy-4-[(2S)-2-[(methoxycarbonyl)amino]-3,3-dimethyl-N'-\{[4-(7yridine-2-yl)phenyl]methyl $\}$ butane hydrazido]-1-phenylbutan-2- yl]carbamoyl\}-2,2-dimethylpropyl]carbamate [Fig. 1]

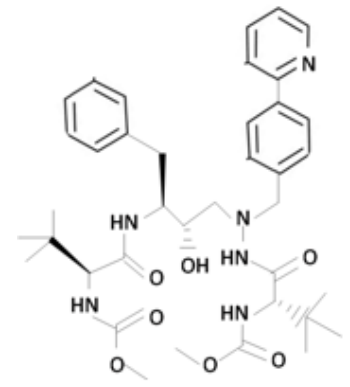

Fig. 1: Chemical formula of Atazanavir $\left(\mathrm{C}_{38} \mathrm{H}_{52} \mathrm{~N}_{6} \mathrm{O}_{7}\right)$ Source: National Center for Biotechnology Information. PubChem Database. Atazanavir, $C I D=148192$,

https://pubchem.ncbi.nlm.nih.gov/compound/Atazana vir (accessed on May 25, 2019)

*email:dumitrui@hotmail.com,adrianbeznea@hotmail.com 
The mechanism of action of ATV is to bind by the active site of the protease and inhibition of enzymatic cleavage of the viral polyprotein. Consequently, HIV replication under ATV produce immature and non-infectious viral particles. Several years ago, ATV was thepreferred IP drug, recommended both in the first line and in the second line of treatment [6]. The decrease in susceptibility to ATV was associated with occurrence of viral mutations, highlighted by phenotypic analyzes. Co-administration of ATV with other drugs may alter their plasma levels, due to competitive liver metabolization by cytochrome P450. Side effects may be transient and asymptomatic increase in liver enzymes, exacerbation of co-infection with hepatitis $\mathrm{B}$ or $\mathrm{C}$ viruses, the moderate increase unconjugated bilirubin related to deficiency of uridine diphosphate glucuronosyltransferase UAGT1A1. Over $40 \%$ of patients may develop unconjugated hyperbilirubinaemia, but less than $2 \%$ may require ATV discontinuation [7].

\section{Experimental part}

The experience of ATV therapy from January 2009 to January 2019 was retrospectively analyzed in HIV infected patients from Galati. The study was approved by the Ethics Council of "Dunarea de Jos" University from Galati. Patients were investigated and monitored according to local protocols and recommendations of European AIDS guidelines [8]. We analyzed the durability of ATV therapy, demographic data, age of HIV diagnosis, co-infections with hepatitis viruses, therapeutic experience prior to ATV regimen, immunological and virological evolution, bilirubin level and the reasons for giving up ATV. Each patient with ATV was analyzed from baseline to end-point treatment.

Immunity objected by lymphocytes LCD4 count was assessed by flow cytometry, and HIV viral load (VL)was assessed by the polymerase chain reaction technique (PCR). The detection limit of VL was 20 copies/ml or 400 copies/ml. We considered a virological response if HIV RNA was $<400$ copies $/ \mathrm{ml}$.

The data were analyzed using the SPSS18 program. The threshold of statistical significance was $\mathrm{p}, 0.05$. We used the Mann-Whitney and Kruskal-Wallis tests for categorial data and Chi-square test for numerical data.

\section{Results and discussions}

We have identified 60 patients exposed to ATV containing regimens, of which $26.6 \%(16 / 60)$ with the first-line ARV and $73.3 \%$ (44/60) with previous treatment with IP regimens (31/44) or other ARV classes (13/44). The median number of previous treatment regimens was 2 and ranged from 1 to 10. The average duration of HIV diagnosis until the beginning of the ATV regimen was $7.1 \pm 6.8$ years, with variations from a few weeks to 26 years. Choosing ATV therapies were justified as following: $26.6 \%$ guidelines recommendations for the first-line ARV, $46.6 \%$ failures of previous therapy, $18.3 \%$ adverse events of previous therapy, especially metabolic and cardiovascular events, $8.3 \%$ improving convenience for better adherence of experienced patients [9] .The pre-existing cardiovascular co-morbidities that counted for choose ATV as preferred PI were hypertension (18/60), cardiomyopathy (4/60), myocardial infarction (1/60), ischemic heart disease (2/60) and stroke $(1 / 60)[10,11]$. Combination antiretroviral therapies can be atherogenic and could increase stroke risk. Atazanavir was associated with backbone Lamivudine/Abacavir (80\%), Tenofovir/Emtricitabine (13.3\%) or other backbone drugs $(0.6 \%)$.

Demographic characteristics were: mean age $32.45+/-12.34$ years, 34/26 gender ratio, $46.6 \%$ transmission pattern of nosocomial HIV infected pediatric cohort from the 1990s [12]. The risk behaviors were: $56.6 \%$ smoking, $20 \%$ alcohol consumption. There were no intravenous drug users. Most enrolled patients had experienced advanced immunosupression, as median of lowest CD4 values was $183.5 / \mathrm{mm} 3$ [3; 732] and $45.2 \%(26 / 60)$ patients associated opportunistic diseases, especially tuberculosis (20/26). Markers of hepatitis B virus were present in $46.6 \%(28 / 60)$ patients, while none hepatitis C co-infection was found.

Therapies with ATV were initiated from 2009 until 2016, when updated recommendations of treatment guidelines for the first-line antiretroviral have been preferred other novel drugs [10].

Lower LCD4 and higher HIV viral load in naive patients than PI experienced group were presented in the baseline of Atazanavir treatment.[Table 1].

The mean duration of ATV therapy was $4.5+/-2.75$ years but 34 patients dropped out of therapy, 8 of them in the first year and 9 in the second year. There were no deaths during ATV treatment.

Table 1

CHARACTERISTICS IN THE BASELINE OF ATAZANAVIR TREATMENT

\begin{tabular}{|l|l|l|l|l|l|l|l|}
\hline N=60 & PI Experience & Average & St. Dev. & Median & Max & Min & P \\
\hline AGE & No (29) & 33 & 13.00 & 31 & 80 & 18 & 0.741 \\
\cline { 2 - 8 } Years & Yes (31) & 31.93 & 11.88 & 27 & 60 & 19 & \\
\hline Baseline & No (29) & 320.24 & 1.00 & 310 & 844 & 34 & 0.013 \\
\hline
\end{tabular}




\begin{tabular}{|l|l|l|l|l|l|l|l|}
\hline LCD4/mm & Yes (31) & 486.80 & 0.46 & 481 & 1143 & 3 & \\
\hline \multirow{2}{*}{$\begin{array}{l}\text { Baseline } \\
\text { Viral load c/ml }\end{array}$} & No (29) & 172214 & 324500 & 44762 & 1233785 & 20 & 0.041 \\
\cline { 2 - 8 } & Yes (31) & 36097 & 85250 & 2115 & 423657 & 20 & \\
\hline $\begin{array}{l}\text { Bilirubine } \\
\text { mg/dl }\end{array}$ & No (29) & 0.47 & 0.28 & 0.42 & 1.38 & 0.1 & 0.127 \\
\cline { 2 - 8 } & Yes (31) & 0.55 & 0.24 & 0.44 & 1.23 & 0.24 & \\
\hline
\end{tabular}

The main cause of stopping ATV were the occurrence of jaundice, even though most of these patients achieved viral suppression (17/18) with no correlation between the groups on first-line treatment and PI pretreated. Other rare reasons for ATV withdrawal were drug-drug interactions (DDI), other adverse events (diarrhea, renal toxicity), loss from care or the abandon by adherence deficiencies [Fig. 2].

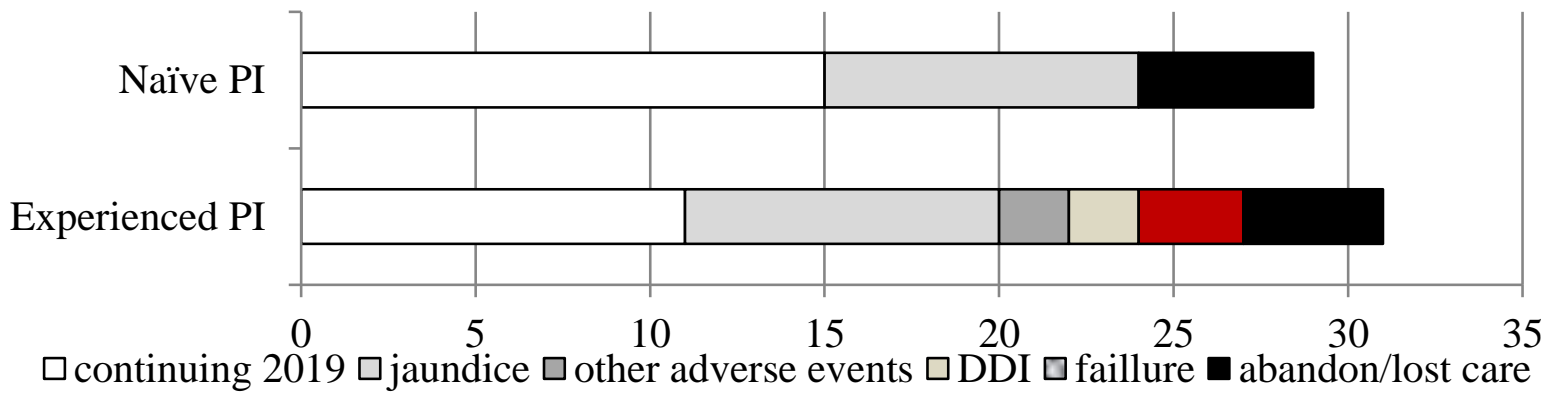

Fig. 2. The outcome of Atazanavir regimens in naive and PI experienced patients

Pregnancy during ATV treatment was monitored in three women and all of them gave birth to healthy babies, without neonatal incidents.

The trend of LCD4 was favorable under ATV regimens. Comparing the baseline, the level increased with average $81 / \mathrm{mm}^{3}$ in the first year, $115 / \mathrm{mm}^{3}$ in the second year and maintained above $500 / \mathrm{mm}^{3}$ the average LCD4 values, for over 8 years [Fig. 3].

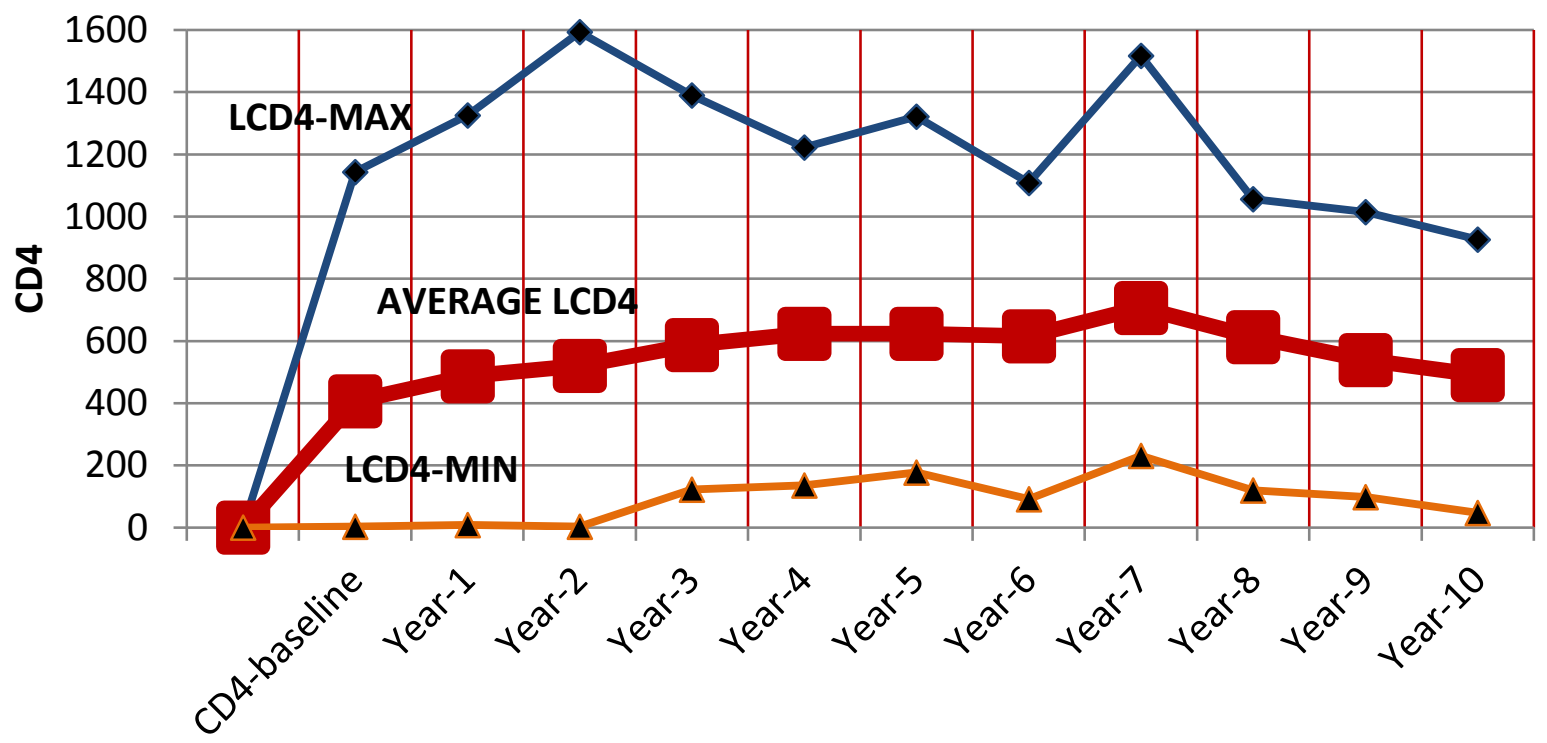

Fig. 3. Evolution of CD4-count underAtazanavir treatment: over 10 years experience

Suppressed viral load under 400 copies $/ \mathrm{ml}$ in the first year of treatment was obtained in $83.3 \%$ of patients. The virologic response rate was over $80 \%$ per year [Fig. 4].

End-point biological data highlights the safety of ATV use. Elevated liver enzymes over 1.5 upper limit of normal (ULN) were found in 18 patients (30\%), without correlation with HBV co-infection or bilirubin level. Elevated levels of bilirubin was presented to $81.6 \%$ (49/60) patients, and was an aesthetic reason for renounce to ATV [Table 2]. 


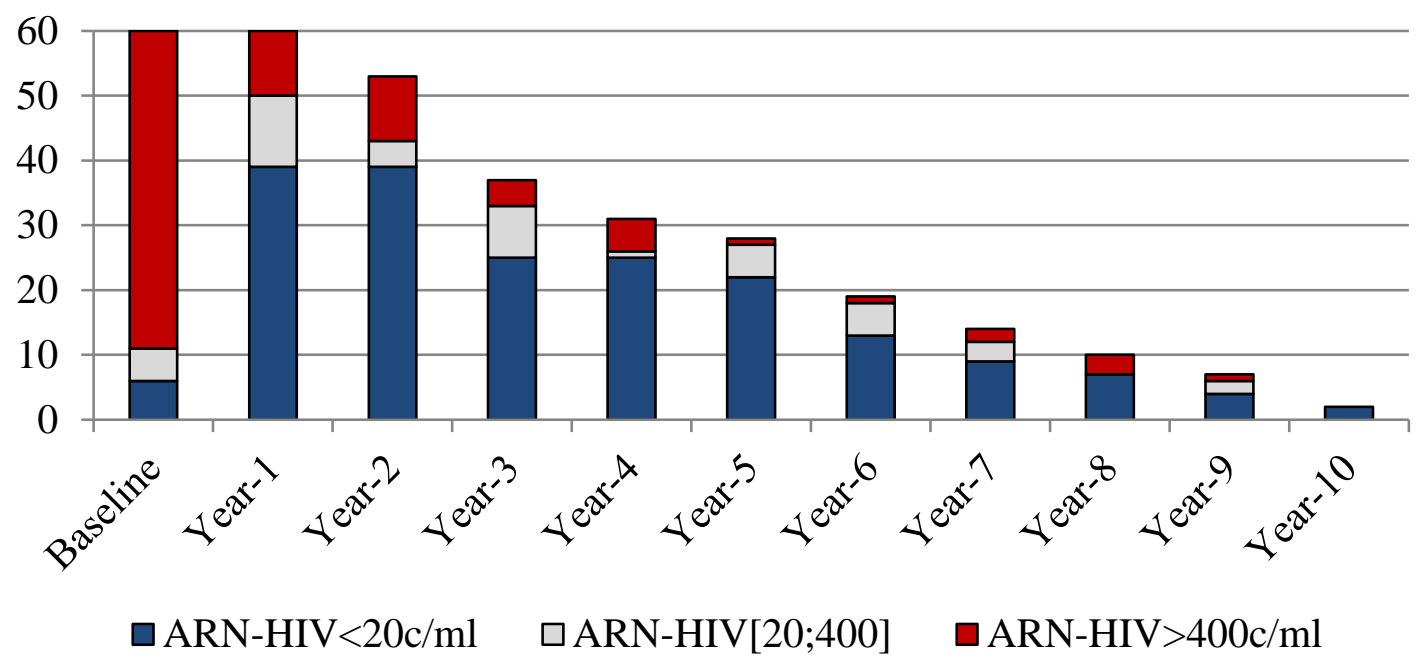

Fig. 4.Virological outcome on Atazanavir treatment:over 10 years experience

Table 2

CHARACTERISTICS IN THE END-POINT OF ATAZANAVIR TREATMENT

\begin{tabular}{|c|c|c|c|c|c|c|c|}
\hline $\mathrm{N}=60$ & PI Experience & Average & St. Dev. & Median & Max & Min & $\mathrm{P}$ \\
\hline \multirow{2}{*}{$\begin{array}{l}\text { Bilirubin } \\
\mathrm{mg} / \mathrm{dl}\end{array}$} & No (29) & 3.19 & 2.23 & 2.59 & 9.13 & 1.58 & 0.870 \\
\hline & Yes (31) & 2.99 & 1.90 & 2.59 & 7.08 & 1.61 & \\
\hline \multirow{2}{*}{$\begin{array}{l}\text { ALT } \\
\text { UI/L }\end{array}$} & No (29) & 36.44 & 25.00 & 26 & 98.2 & 9 & 0.395 \\
\hline & Yes (31) & 32.29 & 21.41 & 23 & 94.7 & 11 & \\
\hline \multirow{2}{*}{$\begin{array}{l}\text { AST } \\
\text { UI/L }\end{array}$} & No (29) & 27.30 & 11.91 & 24.3 & 67 & 14.2 & 0.257 \\
\hline & Yes (31) & 23.73 & 7.68 & 22.4 & 48.7 & 13 & \\
\hline \multirow{2}{*}{$\begin{array}{l}\text { Creatinine } \\
\mathrm{mg} / \mathrm{dl}\end{array}$} & No (29) & 0.90 & 0.16 & 0.88 & 1.24 & 0.61 & 0.115 \\
\hline & Yes (31) & 0.83 & 0.22 & $0 \backslash .79$ & 1.53 & 0.59 & \\
\hline
\end{tabular}

The cumulative incidence of hyperbilirubinaemia in our study is similar to results of a Canadian study on ATV versus another IP in over 1150 patients followed up for 9 years, with $83.6 \%$ jaundice [13]. Furthermore, recent experimental studies provide arguments for increasing antioxidant capacity and improving endothelial function in patients with type 2 diabetes who have ATV-induced hyperbilirubinemia, with values between 4 and $3.8 \mathrm{mg} / \mathrm{dl}$. Bilirubin is one of the most powerful antioxidants that could contribute to delaying atherosclerosis, inhibiting low-density lipoprotein formation (LDL). Thus, increased bilirubin levels have been shown to be associated with lower cardiovascular risk [14,19] . For example, Gilbert syndrome, characterized by congenital hyperbilirubinaemia, has cardiovascular disease mortality 3 times lower than general population $[15,20,21,25]$. The level of hyperbilirubinemia after ATV treatment is influenced by genetic factors, with higher values in the slow metabolizing genotype of UGT1A1 [16,22]. In our study, elevated bilirubin correlated with ATV constant exposure in ARV adherent patients $(\mathrm{p}=0.002)$, with aesthetic reasons $(\mathrm{p}=0.016)$ and non-smoking status $(\mathrm{p}=0.025)$. The correlation between the decrease of indirect bilirubin in smokers was demonstrated by previous studies [17,23,]. These data support the variability of hyperbilirubinemia associated with ATV use [13, 18, 24].

\section{Conclusions}

Atazanavir is still used in ARV regimens, proving effective and safe after 10 years of practical use, in both naive and experienced patients. The frequent hyperbilirubinemia related to Atazanavir has not significance for health, is variable depending on genetic factors, and associates lower cardiovascular risk perspective than others IPs. Worldwide, Atazanavir saved many lives in the fight anti-AIDS, has written a page in the history of ARV and was a lesson for therapeutic practice. However, the guidelines recommendations are continuous changing, as other new more efficient drugs are developing, with hope of HIV cure in the future.

\section{References}

1.SEVERE, P., JUSTE, M.A.J., AMBROISE, A., ELIACIN, L.,MARCHAND, C., APOLLON,S.,et al., N Engl J Med., 363, no.3, 2010 , p. $257-256$. 2. HOFFMANN, C., ROCKSTROH, J.K.., HIV 2015/2016, 23rd edition, MedizinFokusVerlag (Hamburg), 2015 p 64-246.

3. GÜNTHARD, H.F., CALVEZ, V., PAREDES, R., PILLAY, D., SHAFER, R.W., WENSING,A.M., JACOBSEN, D.M., RICHMAN, D.D., Clin Infect Dis, 68, no. 2, 2019, p. 177-187. 
4. ARBUNE, M., POTÂRNICHIE, O.M., PASARIN, L., MARTU S. REV ROM BIOET, 12, no.1, 2014, p. 72-79.

5. PATEL, D.A., PATEL, C.N., Drug Dev Ther, 6, 2015, p. 1-4

6. WOOD, R., Expert Rev Anti Infect Ther., 6, no.6, 2008, p. 785-796.

7. PERLOFF, E.S., DUAN, S.X., SKOLNIK, P.R., GREENBLATT, D.J., VON MOLTKE, L.L., Drug MetabDispos, 33, no.6, 2005 , p. 764-770.

8.DASCALU, C.G., ANTOHE, M.E., GOLOVCENCU L., ET AL., 2017 IEEE INTERNATIONAL CONFERENCE ON E-HEALTH AND BIOENGINEERING CONFERENCE (EHB) BOOK SERIES: E-HEALTH AND BIOENGINEERING CONFERENCE, 2017, PAGES: 462-465

9. REISS, P., BATTEGAY, M., CLUMECK, N., MULCAHY, F., ARRIBAS, J., D’ARMINIO-MONFORTE, A., GATELL J., GERETTI, A.M., KATLAMA, C., LUNDGREN J., POZNIAK A., ROCKSTROH, J., BONN, YOULE, M., EACS Guidelines vs.5, 2008 , p. 8-22.

10.LAFLEUR, J., BRESS, A. P., ROSENBLATT, L., CROOK, J., SAX, P. E., MYERS, J., RITCHINGS, C. AIDS (London, England), 31, no. 15, 2017, p. 2095-2106.

11.CUCIUREANU DI, CONSTANTINESCU IM, DANCIU F, CUCIUREANU T. Epilepsia; 2015; 56(suppl. 1): $128 . p 0516$.

12 CIOCAN-PENDEFUNDA,A.A.,MARTU,M.A.,ANTOHE,M.E.ET AL., ROMANIAN JOURNAL OF ORAL REHABILITATION, 10 (4), 2018 PAGES: $91-96$

13. COLAFIGLI M ET A.L., HIV MED, 9, no.3, 2008, p. 172-179.

14. LUNDGREN, J.D., EACS Guidelines vs. 8.2, 2017, p. 7-17.

15. JUGULETE, G., IACOB, S., MERISESCU M., LUMINOS M., Rev. Chim.(Bucharest), 68, no. 11, 2017, p. $2467-2470$.

16.SCUTARIU, M. M.; CIURCANU, O. E.; FORNA AGOP, D., et al.,MedicaL-SurgicalJournal Volume: 120 Issue: 4 Pages: $926-$ 931 Published: 2016

17. LAPRISE, C., BARIL, J. G., DUFRESNE, S., \& TROTTIER, H. AIDS Patient Care STDS, 27, no.7, 2013, p. $378-386$.

18.STOIAN, A.; EARAR, K.; BUDACU, C.; ET AL., Rev.Chim.(Bucharest), 67, no. 11 ,2016, P.: 2355-2359

19. DEKKER, D., DORRESTEIJN, M.J., PIJNENBURG, M., HEEMSKERK, S., RASING-HOOGVELD, A., BURGER, D.M., WAGENER, F.A., SMITS, P., ArteriosclerThrombVasc Biol., 21, no.2, 2011, p. 458-63.

20. HIRSCHFIELD, G.M., ALEXANDER, G.J., Ann ClinBiochem, 43. 2006, p. 340 -343.

21.EARAR, K., GRADINARU,S., PARIZA ,G., ET AL., Rev. Chim. (Bucharest), 68 , no. 8, 2017, p. 1868-1873

22. KATSUKI, M., NAKAMURA, Y., HIRANO, M., NOMOTO, K., IMAI, M., J-STAGE, 29, no.1, 2014, p. 9-14.

22.LEGER, P., CHIRWA, S., NWOGU, J. N., TURNER, M., RICHARDSON, D. M., BAKER, P., HAAS, D. W., Pharmacogenet Genomics, 28, no.1, 2018, p.1-6.

24. DIRTU, D., LUNGU, N.C., CHIRITA,P., ET AL., REV.CHIM.,67, no. 3 , 2016, p.: 534-537

25. CUCIUREANU, D.I., CUCIUREANU, T., CUCIUREANU, A., Neurotic disorder and unexpected EEG records in apparent healthy people. [abstract no. p935]. Journal of the Neurological Sciences. 2017; 381 (suppl S): 339.

$\overline{\text { Manuscript received: } 14.11 .2019}$ 